\title{
CEILING FAN - AN ENERGY GENERATOR (REUSABLE ENERGY)
}

\section{NIKHIL KUMAR \& SHRAWANI CHOUGULE}

Student, Aeronautical Engineering Department, Sathyabama Institute of Science and Technology,

\author{
Chennai, India
}

\begin{abstract}
The aim of this research paper is to recycle the energy wasted by us which is used by ceiling fan. Here, we are using fans for only cooling effect, however, we never think of its higher energy consumption. The theoretical scope of this paper is about not wasting this precious energy but reuse it. For this, certain experiment Dynamo played a major role in it which provides us further power supply through the rotational movement of fan. Dynamo converts the mechanical energy into electrical energy by using the electromagnetic induction principle. Here, another material also plays an important role in this experiment which is the Step-up high voltage generator module. The main purpose of this step-up high voltage generator is to increase the output low voltage into high voltage with the help of which we can run different appliances. Now, the key component of the project is the Gear mechanism. It is a key component because it increase the rotation of the Dynamo due to which we get more voltage due to fast rotation.

KEYWORDS: Reusable Energy, Dynamo, Electromagnetic Induction, Step-up High Voltage Generator Module \& Gear Mechanism
\end{abstract}

Received: Apr 08, 2020; Accepted: Apr 28, 2020; Published: Jul 07, 2020; Paper Id.: IJAERDDEC20202

\section{INTRODUCTION}

The "CEILING FAN A POWER GENERATOR" project is for the poor and middle class family people who always have an issue of paying electricity bill of such a huge amount. The fan with reusable energy sounds too much interesting and yes it is possible to do with it. We are just ignoring the value of having fan in a home. We are wasting approx. $155 \mathrm{~V}$ at the moment of time when we start using fan in our home. We have to use that power and bring it in our daily use and we can store this reusable energy in form of batteries also.

Here, Dynamo perform an important role. We know, as per the records, the dynamo can produce the electricity upto average 5 volts, if the rpm of the object is about 400. So, the average fan angular speed is about 400 $\mathrm{rpm}$. As per the calculations, if dynamo gets that much rpm, so it can produce 5 volts electricity per minute and this is all because of the principle of Electromagnetic induction.

Electromagnetic (or) magnetic induction is the production of electromotive force (i.e., voltage) across an electrical conductor in a changing magnetic field. It uses the magnetic flux through a region of space enclosed by a wire loop. The direction of the electromotive force is given by Lenz's law which states that an induced current will flow in the direction that will oppose the change which produced it.

Now the term for Step-up high voltage generator module due to which the amount of induced current produced by the dynamo it is increased to at that extent by which we can run our home appliances very frequently it is consists of capacitors, resistors, diodes and the outer body is made by the ceramics layer . Here ceramics layer are 
used because as we all know that ceramics layers absorb too much amount of heat so that's why ceramics body is used.

This is the last item, but the key component of our project. It is Speed up Gear mechanism as the name suggest you that it speeds up mechanism and increase the angular velocity of the dynamo more than its normal rotation due to which the production of the electricity increased.

\section{MATERIALS}

\section{1:-Dynamo Parts and this Material Selected}

- Body - 6061 aluminium alloy

- Clamp - Glass Filled Nylon

- $\quad$ Spring - Stainless steel

- $\quad$ Side Links - ABS plastic

- Roller - 6061 Aluminium alloy

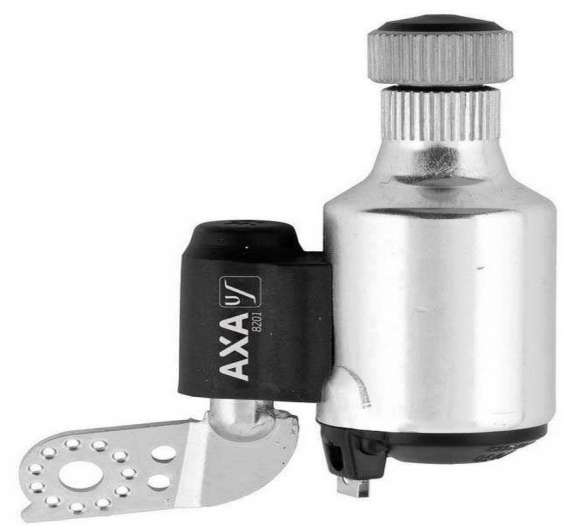

Figure 1

\section{2:-Step-up Power Module High Voltage Generator}

- Ceramics body

- Capacitors

- Resistors

- 20 diodes(30 ohms)

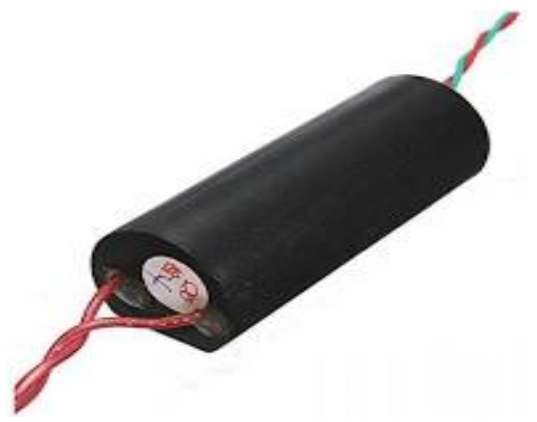

Figure 2 


\section{3:-Voltage Regulator}

It regulates output voltage.

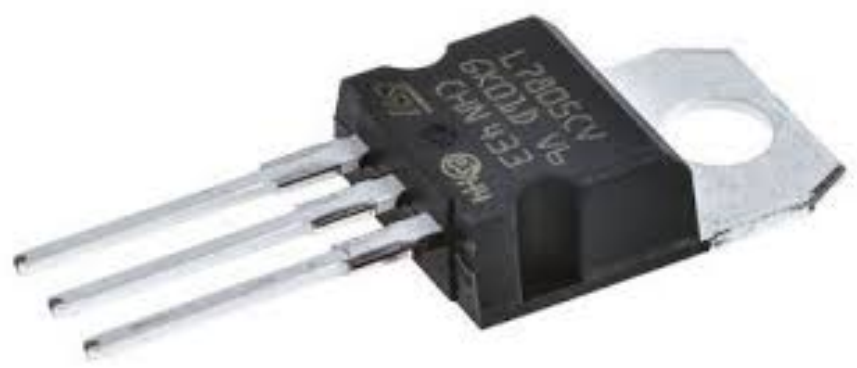

Figure 3

\section{4:- Speed up Gear Mechanism}

- Stainless steel.

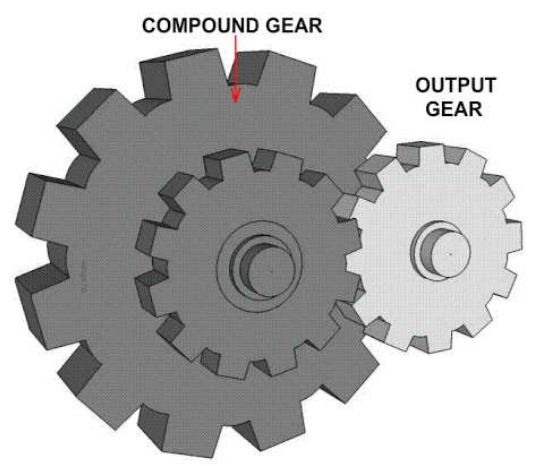

Figure 4

\section{Ceiling Fan}

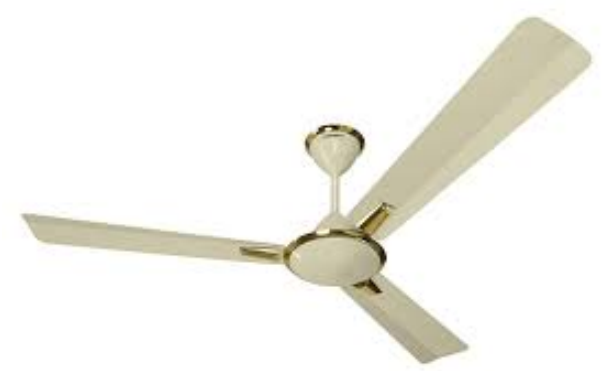

Figure 5

\section{METHODOLOGY}

Every day we are facing that the poor and middle class people are struggling to pay the electricity bill at that moment when we see this fan and the bicycle wheel there is no anymore difference between them and from there this concept generates and now it's take a form of research between us. 
Methods which we are using in this paper is based on simple electric appliances product, we are doing this project on small fan's at first to have a closure look into the design and if there is any issue came then due to using it in small fan we can easily point out the problem.

The basic thing which we are doing is particularly, preparing the circuit diagram for each and every phase of the project whether the circuit break happen or frequency down take place so point by point we are having full focus over it.

In this paper no any software is used because we are not making the difference in the basic design of ceiling fan but we are just adding the new component over it so for the testing purpose we have to practically go through the procedure as that was mentioned in this paper. The mounted Dynamos over the body of the fan, will get high rotation due to the presence of speed up gear mechanism before the dynamo and later on the circuit connection with the attached stepup voltage generator increase the output voltage to some good extentand at last voltage regulator balanced the output voltage which is coming form the step-up voltage generator module.

\section{RESULTS AND CONCLUSIONS}

\section{Results}

The overall result we are getting from this project is that we are finally going to generate sufficient amount of electricity (i.e.155v) on that basis we can use it for home appliances and it will help in reducing the electricity bill.

\section{CONCLUSIONS}

By using this ceiling fan, we will be able to regenerate electricity that will help us in running our home appliances efficiently.

\section{REFERENCES}

1. https://www.instructables.com/community/Charge-batteries-with-a-bike-dynamo/.

2. https://sites.google.com/site/me122bikehubdynamo/hardware-implementation/electrical-hardware/mechanical-hardware.

3. https://www.google.com/url?sa=t\&source=web\&rct=j\&url=https://www.quora.com/How-much-electricity-can-a-12V-DCmotor-generate\&ved=2ahUKEwiv8LqLyOLoAhXoyzgGHWG_Bs8QFjAMegQIAhAB\&usg=AOvVaw0R5dzhdD6XVfiyoJo65sw.

4. https://www.google.com/url?sa=t\&source=web\&rct=j\&url=https://www.quora.com/A-dynamo-running-in-250-rpm-willproduce-how-much-

power\&ved=2ahUKEwjRjr22yOLoAhVVxzgGHViaDugQFjAAegQIARAB\&usg=AOvVaw0ChhQ4JepYOMYpYAX9e7W\&cshid=1586683456623.

5. https://www.google.com/url?sa=t\&source=web\&rct=j\&url=https://www.quora.com/What-is-the-difference-between-a-DCmotor-and-a-dynamo\&ved=2ahUKEwjJvJHOyOLoAhUuyDgGHQBTCKkQFjAMegQIAxAB\&usg=AOvVaw0OJWqlxfGwfR29Od3KZXz.

6. https://www.google.com/url?sa=t\&source=web\&rct=j\&url=https://michaelbluejay.com/electricity/bicyclepower.html\&ved=2 ahUKEwiOmvLsyOLoAhXSzzgGHQ39CJEQFjARegQIDhAJ\&usg=AOvVaw09IXZoE5OCm79FTWwYE-Mj.

7. Chowdary, Undavalli Vivek, et al. "Home automation system using IR sensors." International Journal of Electrical and Electronics Engineering 4.6 (2015): 11-1. 
8. https://www.google.com/url?sa=t\&source=web\&rct=j\&url=https://www.quora.com/Whats-the-reasonable-electricalefficiency-that-can-be-expected-from-adynamo\&ved=2ahUKEwiOmvLsyOLoAhXSzzgGHQ39CJEQFjAOegQICxAx\&usg=AOvVaw3OtvuBhozuozGfvNIkTnuO.

9. https://www.google.com/url?sa=t\&source=web\&rct=j\&url=https://www.eeweb.com/forum/torque-of-ceilingfans\&ved $=2$ ahUKEwiYoJXgyeLoAhXxTgGHcdcDW4QFjAAegQIARAB\&usg=AOvVaw0zi8b2gIi_OUo5uPuID8yj\&cshid=1586683817470.

10. S. Kumar, M., B. Veerabhadra Reddy, and P. Venkateshwar Reddy. "Experimental Comparison of Solar Paraboloid Collector with and without Mirror in Aluminum Foil as Reflectors." International Journal of Mechanical and Production Engineering Research and Development (IJMPERD) 8.2 (2018): 1117-1124.

11. https://www.google.com/url?sa=t\&source=web\&rct=j\&url=https://www.hansenwholesale.com/ceiling-fans/ceiling-fanrpms\&ved=2ahUKEwil-buIyuLoAhVdzjgGHUuvCdEQFjAAegQIAhAB\&usg=AOvVaw1NqWJK6TRHgh_oXO-pOaPj.

12. https://www.google.com/url?sa=t\&source=web\&rct=j\&url=https://www.quora.com/What-is-a-dynamo-and-how-does-itwork-with- $a$ motor\&ved=2ahUKEwiBtpjH0OLoAhVWyDgGHSTbCj4QFjACegQIDhAI\&usg=AOvVaw3Hr8aPJrN8Mj59HM6o6QAz.

13. Garg, Chirag, and Aakash Jain. "Green concrete: Efficient \& eco-friendly construction materials." International Journal of Research in Engineering \& Technology 2.2 (2014).

14. https://www.google.com/url?sa=t\&source=web\&rct=j\&url=https://www.quora.com/What-is-the-difference-between-a-DCmotor-and-a-dynamo\&ved=2ahUKEwjlvont0OLoAhWYzzgGHc4iDPsQFjABegQIDRAF\&usg=AOvVaw0OJWqlxfG$w f R 29 O d 3 K Z X z$

15. Girish, C. R. "Review of various feedstocks used and the operating conditions for biodiesel production." International Journal of Mechanical and Production Engineering Research and Development (IJMPERD) 8.4 (2018): 357-370.

16. https://www.google.com/url?sa=t\&source=web\&rct=j\&url=https://en.m.wikipedia.org/wiki/Dynamo\&ved=2ahUKEwiE8cal OeLoAhVdzDgGHT31DJEQFjAEegQIDxAJ\&usg=AOvVaw05i-a-CVq4kUb3eY9WboSV.

17. https://en.wikipedia.org/wiki/Electromagnetic induction. 
